\title{
Application of research in the field of forensic entomology for determining the time of death in dogs
}

\author{
PIOTR LISTOS, MAGDALENA GRYZIŃSKA*, JUSTYNA BATKOWSKA*, \\ MAŁGORZATA DYLEWSKA*, KATARZYNA CZEPIEL-MIL**
}

\author{
Department of Pathological Anatomy, Faculty of Veterinary Medicine, \\ University of Life Sciences in Lublin, ul. Gleboka 30, 20-612 Lublin, Poland \\ *Department of Biological Basis of Animal Production, **Department of Zoology, Ecology and Wildlife Management, \\ Faculty of Biology and Animal Breeding, University of Life Sciences in Lublin, ul. Akademicka 13, 20-950 Lublin, Poland
}

Listos P., Gryzińska M., Batkowska J., Dylewska M., Czepiel-Mil K.

Application of research in the field of forensic entomology for determining the time of death in dogs

Summary

Precisely determined time of death is one of the most important pieces of information obtained during a post-mortem investigation. There are several traditional methods for determining time of death, the most important of which are evaluation of early post-mortem changes, such as the change in body temperature. The study was aimed at identifying insects collected from the body and establishing the time of death by observing the developmental cycle of the indicator species Calliphora vicina. The material for the main experiment was the carcass of a dog. The length of the developmental cycles of insects depends on ambient conditions, so studies should take as many criteria as possible into account. Succession of arthropods, as well as the species composition and indicator insects of particular stages of decomposition, is very similar in human and animal carcasses. The results obtained were considered with respect to the time that had passed since the death of the animal. Experiments on dog carcasses may in the future contribute to the development of research enabling determination of the time of death of animals, which is a subject of increasing interest in forensic veterinary medicine.

Keywords: forensic entomology, necrophagous insects, time since death, Calliphora vicina

One of the most important tasks of forensic medicine is to determine how much time has passed from the moment of death to the discovery of the body (12). At each stage of decomposition the food and environment provided by the body are ideal for the development of various groups of invertebrates known as scavengers. Alongside conventional methods, once the necrophagous forms or the traces they have left at the scene of the incident have been collected and identified, such evidence may be an important factor in determining the time of death.

Estimation of the time of death is a difficult task often subject to error, which is closely correlated with the time passed since the death. The more time has passed, the more difficult and less precise the analysis will be. Within the first few days after death early signs of death are examined, including the development of lividity and rigor mortis and the decrease in body temperature $(11,17)$. Other tests include determination of the degree to which the cornea has dried out. Interlethal reactions in tissues are analysed as well. This involves evaluation of the response of the skeletal muscles to an external stimulus, which may be mechanical (Zsako's phenomenon) or electrical, or the response of the pupil to drugs causing pupil constriction (e.g. pilocarpine or acetylcholine) or dilation (e.g. atropine), placed in the conjunctival sac or injected into the anterior chamber of the eye $(6,10,21)$.

Knowledge from the field of entomology is unfortunately still rarely applied as an alternative method for determining time of death. We can distinguish two main procedures, depending on how much time has passed since the death: the development method and the succession method. The first involves analysing the development of insects and establishing how long they have been developing on the body. Following determination of the age of the insects and their preimaginal stages, they are compared to developmental models found in the literature. This is the method used most often in the first few month after death, mainly with flies of the family Calliphoridae, which are first to colonize the body and are a typical indica- 
tor species. The second method is based on analysis of the succession of arthropods colonizing the body. Necrophagous fauna changes during decomposition, and these changes can be exploited to determine the time of death even after several months (14). In our study we put forth the hypothesis that selected larval stages of the fly Calliphora vicina are characteristic for a particular time after death in connection with the environmental conditions prevailing where the body is located and the dynamics of changes in selected signs of biological death.

A fresh carcass in the context of entomological estimation of time of death is one found within one month after death. Within the first 48-72 hours coroners mainly use routine methods for estimating time of death. Unfortunately, after this time these methods are usually not reliable and entomology takes their place.

In forensic practice most bodies are unburied, so the fauna of such carcasses has been studied in detail and is best known. Research was begun by the French scientist Megnin (15) in the nineteenth century in his work La faune de cadavres, in which he described eight links of arthropod succession. Contemporary entomologists still base their work on Megnin's theory, especially within the temperate climate zone. The number of stages of decomposition and links of succession and the quantitative and qualitative composition of fauna depend on the location of the body and how it is concealed. In the case of unburied bodies there are eight links, but in the case of bodies that are buried or immersed in water there are five and six, respectively.

The objective of the study was to determine the type
The aim of the study was to establish the time of death of a dog by comparing the entomological material collected from the carcass with the developmental cycle of the blowfly Calliphora vicina.

\section{Material and methods}

Two experiments were performed: the pilot experiment and the main experiment. In the pilot experiment we determined the differences in the qualitative structure of the fly Calliphora vicina of the family Calliphoridae depending on the type of meat substrate in laboratory conditions. The pilot study was conducted in autumn (October and November). We placed pork outside a building so that Calliphora vicina could lay eggs on it and waited until the first-instar larvae (L1) appeared. Then the larvae were transferred to three different substrates. We used $250 \mathrm{~g}$ of pork shoulder (group I), turkey liver (group II) and pork liver (group III). Then the samples were placed in an FD120 phytotron chamber. During the experiment constant microclimatic conditions were ensured: a temperature of $21.3^{\circ} \mathrm{C}$ and $72.5 \%$ humidity. The results obtained were used to compare the duration of each developmental stage of the fly for each type of food.

The material for the main experiment was the carcass of a mixed-breed dog weighing $7.7 \mathrm{~kg}$, which was euthanized due to advanced cancer. The age of the animal was estimated at about 10 years by examining its teeth. The carcass was placed on the ground in a natural environment and protected from access by humans and animals, and the area was appropriately marked. For 40 days in the spring (March and April) every 3-4 days material was collected for entomological analysis and the temperature and humidity were registered (between 10:00 and 11:00 a.m.). Eggs and insects were collected with tweezers from the surface of of fauna present on an animal (dog) carcass left unburied in the spring in a temperate climate. The study was aimed at identifying insects collected from the body and establishing the time of death by observing the developmental cycle of the indicator species Calliphora vicina. The results obtained were considered with respect to the time that had passed since the death of the animal. The analysis enabled a preliminary determination of the time of death of the animal, while the known, actual time of death was taken into account.
Tab. 1. Percentage share of each developmental stage of Calliphora vicina on successive days depending on the food substrate

\begin{tabular}{|c|c|c|c|c|c|c|c|c|c|c|}
\hline \multirow[t]{2}{*}{$\begin{array}{l}\text { Time } \\
\text { (days) }\end{array}$} & & rk shoul & & & d subst & & & pork live & & \multirow[t]{2}{*}{$\begin{array}{c}\text { Significance } \\
\text { of } \chi^{2} \text { test }\end{array}$} \\
\hline & larvae & pupae & imagines & larvae & pupae & imagines & larvae & pupae & imagines & \\
\hline 9 & 100.0 & & & 100.0 & & & 100.0 & & & - \\
\hline 17 & 18.2 & 81.8 & & 50.0 & 50.0 & & 81.8 & 18.2 & & * \\
\hline 18 & 18.2 & 81.8 & & 25.0 & 75.0 & & 81.8 & 18.2 & & $* *$ \\
\hline 21 & & 100.0 & & 8.3 & 91.7 & & 81.8 & 18.2 & & $* *$ \\
\hline 22 & & 100.0 & & & 100.0 & & 45.5 & 54.5 & & ** \\
\hline 23 & & 100.0 & & & 100.0 & & 9.1 & 90.9 & & - \\
\hline 24 & & 100.0 & & & 100.0 & & & 100.0 & & - \\
\hline 25 & & 100.0 & & & 100.0 & & & 100.0 & & - \\
\hline 28 & & 36.4 & 63.6 & & 81.8 & 18.2 & & 100.0 & & $* *$ \\
\hline 29 & & 18.2 & 81.8 & & 63.6 & 36.4 & & 100.0 & & $* *$ \\
\hline 30 & & 18.2 & 81.8 & & 45.5 & 54.5 & & 100.0 & & ** \\
\hline 31 & & 9.1 & 90.9 & & 36.4 & 63.6 & & 100.0 & & ** \\
\hline 33 & & & 100.0 & & 27.3 & 72.7 & & 54.5 & 45.5 & * \\
\hline 35 & & & & & 27.3 & 72.7 & & 18.2 & 81.8 & - \\
\hline 36 & & & & & & 100.0 & & & 100.0 & - \\
\hline
\end{tabular}

Explanation: * the number of insects in each developmental stage depends significantly on the experimental group $(\mathrm{p} \leq 0.05), * * \mathrm{p} \leq 0.01$ 
the body and its natural orifices, as well as from the close vicinity of the body, and placed in sterile containers. The material was killed by pouring hot water over it and then preserved in a $70 \%$ ethanol solution. The samples were stored in a room with a temperature of $4^{\circ} \mathrm{C}$. The insects were identified using studies and keys for Poland.

Statistical analysis was based on the non-parametric $\chi^{2}$ test.

\section{Results and discussion}

In the pilot experiment the first Calliphora vicina eggs appeared on the meat after three days of exposure (Tab. 1). The presence of larvae was observed after five days. The length of their development was varied. The larvae grown on the pork shoulder and the turkey liver had the shortest development time (8-12 and 8-13 days, respectively). The larvae feeding on pork liver needed slightly more time to develop (8-15 days) (Fig. 1).

Two weeks after the eggs were laid the first pupae began to appear. From this moment the differences in the proportions of each developmental form of the fly were statistically significant. The larvae in group I, feeding on pork shoulder, transformed into pupae fastest, with 9 pupae appearing on the first day, as compared

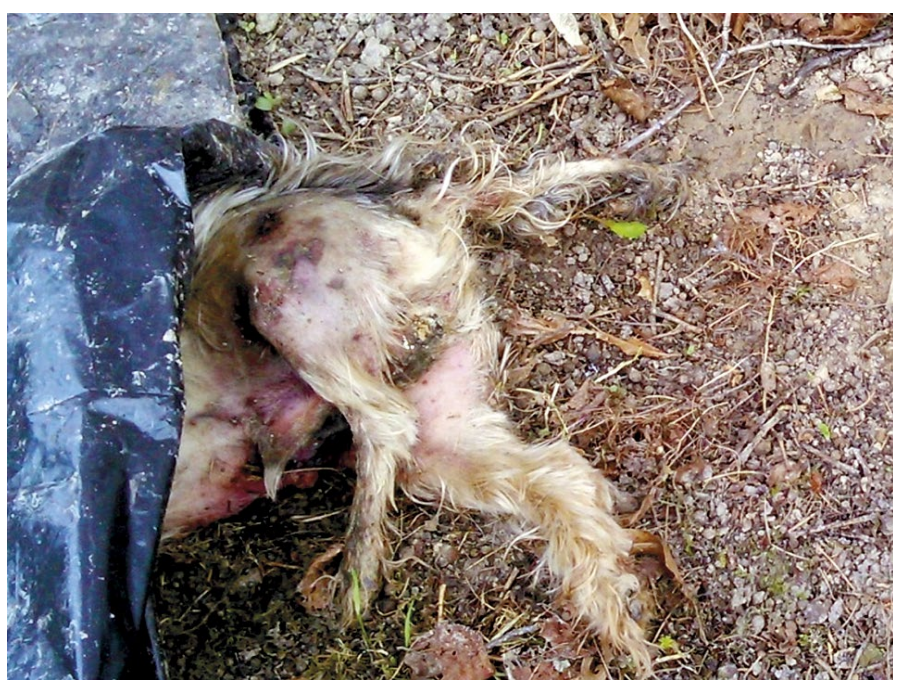

Fig. 2. Dog carcass 9 days after death

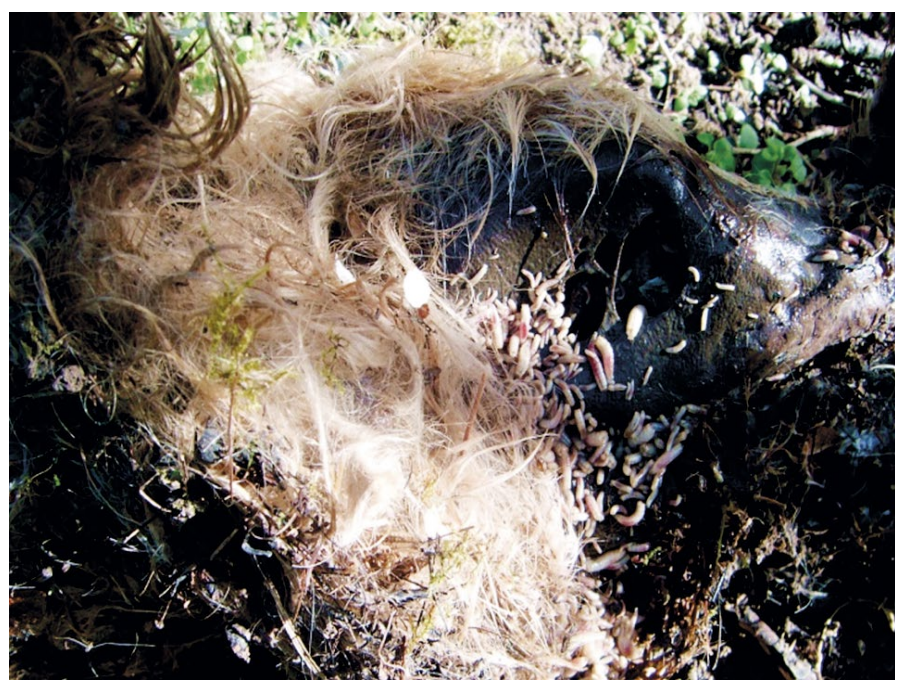

Fig. 4. Dog carcass 25 days after death

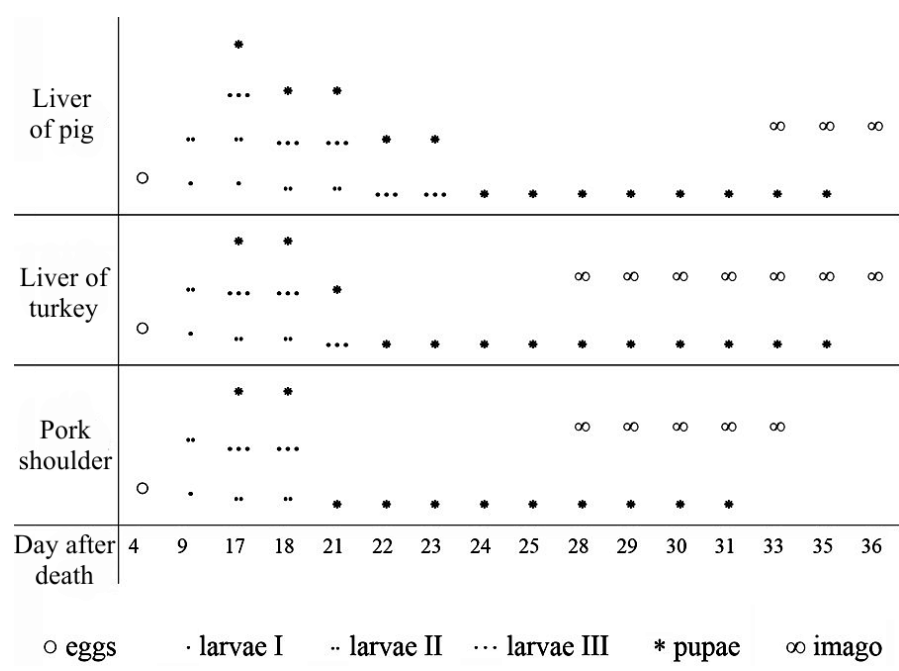

Fig. 1. Developmental stages of $C$. vicina depending on the type of food substrate in laboratory conditions (pilot experiment)

to group II, feeding on turkey liver, with 6 pupae, and group III, feeding on pork liver, with 2 pupae. The pupal stage was shortest in group I at 11-16 days, compared to 11-19 days in group II, while the longest pupal stage was noted for group III, at 1-19 days.

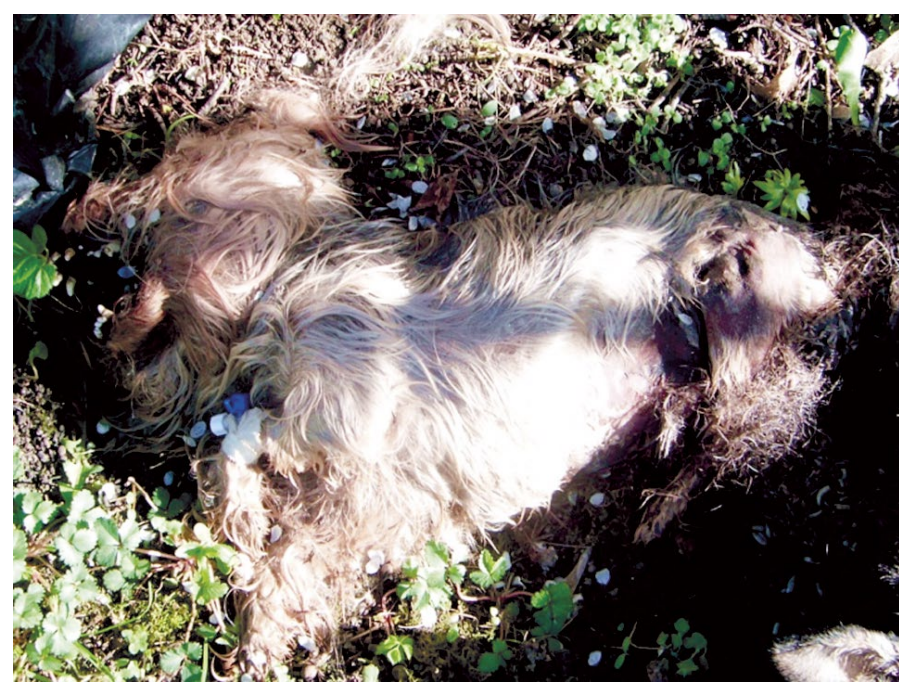

Fig. 3. Dog carcass 15 days after death

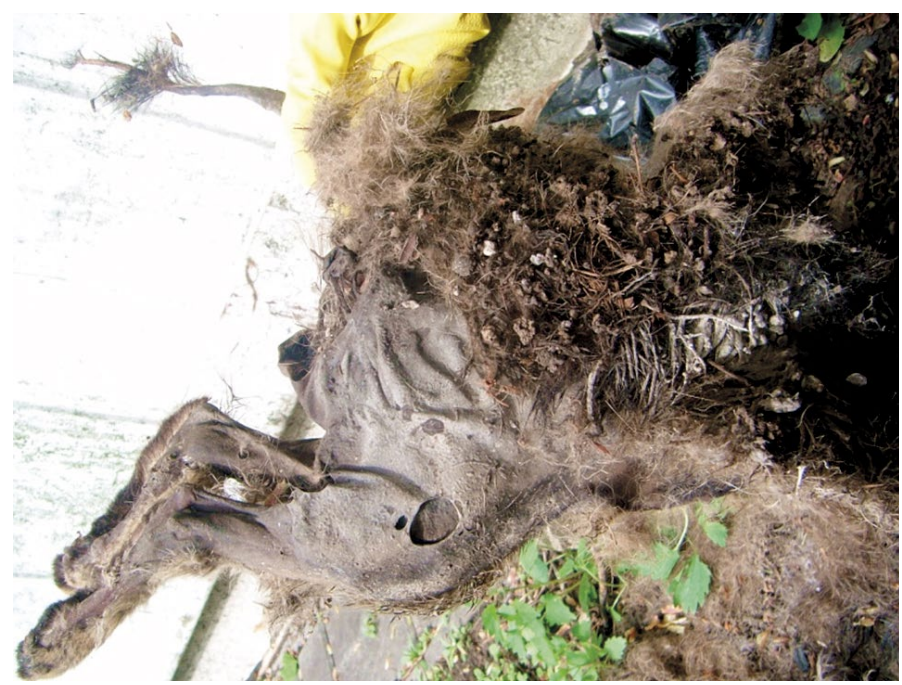

Fig. 5. Dog carcass 36 days after death 
From the $28^{\text {th }}$ day of the experiment the first adult forms of insects were observed in the groups fed on pork shoulder and turkey liver (24 days after the eggs were laid). Adult forms continued to appear for 4 more days in group I and for 7 more days in group II. In the third group the first adult insects did not appear until day 33 of the experiment (29 days after the eggs were laid), and they continued to appear for the next 3 days. A significant difference was also observed in the number of adult forms appearing. In group I seven adult individuals appeared immediately, while there were two in group II and five in group three. The experiment was completed after all pupae had transformed into adults, which occurred earliest in group I (after 33 days of the experiment) and three days later in the other two groups. The shortest developmental period, from laying of eggs to the appearance of the adult form, was noted for the insects feeding on pork shoulder. Their cycle lasted 25-29 days, compared to 24-32 days for the insects feeding on turkey liver, while the longest developmental cycle was noted for the insects feeding on pork liver, at 29-32 days.

The main experiment on the unburied dog carcass enabled observation of the stages of decomposition of the carcass: fresh carcass, autolysis, decay, the begin-
Tab. 2. Entomological material collected from an unburied dog carcass in the spring

\begin{tabular}{|c|c|c|c|c|c|c|}
\hline $\begin{array}{c}\text { Day after } \\
\text { death }\end{array}$ & Phylum & Order & Family & Species & Form & No. \\
\hline \multirow[t]{5}{*}{2} & Arthropods & & Julidae & & & 1 \\
\hline & Arthropods & Diptera & Calliphoridae & Calliphora vicina & & 2 \\
\hline & Molluscs & Stylommatophora & Cochlicopidae & Cochlicopa Iubrica & & 1 \\
\hline & Arthropods & Diptera & & & Fly eggs & 15 \\
\hline & Arthropods & Diptera & & & First-instar fly larvae & 23 \\
\hline \multirow[t]{3}{*}{4} & Arthropods & & Julidae & & & 1 \\
\hline & Arthropods & Diptera & & & Fly eggs & 101 \\
\hline & Arthropods & Diptera & & & First-instar fly larvae & 45 \\
\hline \multirow[t]{3}{*}{9} & $\begin{array}{l}\text { Annelids } \\
\text { (Annelida) }\end{array}$ & & Lumbricidae & & & 1 \\
\hline & Arthropods & Diptera & & & Fly eggs & 182 \\
\hline & Arthropods & Diptera & & & First-instar fly larvae & 46 \\
\hline \multirow[t]{5}{*}{11} & Molluscs & Stylommatophora & & & & 1 \\
\hline & Arthropods & Hemiptera & Pyrrhocoridae & $\begin{array}{l}\text { Firebugs } \\
\text { (Pyrrhocoris apterus) }\end{array}$ & & 1 \\
\hline & Arthropods & Diptera & Calliphoridae & Calliphora vicina & & 2 \\
\hline & Arthropods & Diptera & & & Fly eggs & 83 \\
\hline & Arthropods & Diptera & & & Second-instar fly larvae & 27 \\
\hline \multirow[t]{6}{*}{15} & Arthropods & & Julidae & & & 1 \\
\hline & Arthropods & Diptera & Calliphoridae & Calliphora vicina & & 1 \\
\hline & Arthropods & Hymenoptera & & & & \\
\hline & Arthropods & Diptera & & & Fly eggs & 99 \\
\hline & Arthropods & Diptera & & & First-instar fly larvae & 6 \\
\hline & Arthropods & Diptera & & & Second instar & 28 \\
\hline \multirow[t]{6}{*}{23} & Arthropods & & Julidae & & & 2 \\
\hline & Arthropods & & & & & 1 \\
\hline & Arthropods & Coleoptera & Staphylinidae & Philonthus tenuicornis & & 2 \\
\hline & Arthropods & Diptera & & & First-instar fly larvae & 18 \\
\hline & Arthropods & Diptera & & & Second instar & 42 \\
\hline & Arthropods & Diptera & & & Third instar & 28 \\
\hline \multirow[t]{4}{*}{25} & Arthropods & & Julidae & & & 2 \\
\hline & Arthropods & Diptera & & & Second-instar fly larvae & 17 \\
\hline & Arthropods & Diptera & & & Third instar & 8 \\
\hline & Arthropods & Coleoptera & & & Beetle larva & 1 \\
\hline \multirow[t]{4}{*}{32} & Arthropods & & Julidae & & & 2 \\
\hline & Arthropods & Coleoptera & Staphylinidae & & & 4 \\
\hline & Arthropods & Coleoptera & Cleridae & Necrobia violacea & & 1 \\
\hline & Arthropods & Diptera & & & Third-instar fly larvae & 34 \\
\hline \multirow[t]{5}{*}{36} & Arthropods & & Julidae & & & 4 \\
\hline & Arthropods & Coleoptera & Staphylinidae & & & 2 \\
\hline & Arthropods & Coleoptera & Cleridae & Necrobia violacea & & 1 \\
\hline & Arthropods & Diptera & & & Third-instar fly larvae & 13 \\
\hline & Arthropods & Diptera & & & Fly pupae & 2 \\
\hline
\end{tabular}

nings of fermentation, and finally the beginning of partial desiccation of the carcass (Fig. 2-5).

Identification of the entomological material collected showed that the body was colonized by three classes of 
arthropods: millipedes (Diplopoda), arachnids (Arachnida) and insects (Insecta) (Tab. 2). The most abundant group was insects, and among these flies in various developmental stages. We also collected Gastropoda representing the phylum Mollusca and Oligochaeta representing the phylum Annelida. The following insect species were distinguished: Calliphora vicina, Cochlicopa lubrica, Pyrrhocoris apterus, Philonthus tenuicornis and Necrobia violacea. The first of these, Calliphora vicina, merits particular attention. It is one of the most important indicator species and on the basis of its developmental cycle it is possible to determine approximate time of death.

The development of Calliphora vicina lasts 27.7 days at a temperature of $16^{\circ} \mathrm{C}$ and 29.8 days at $15^{\circ} \mathrm{C}$. The ambient temperature in March and April, measured at 10:00-11:00 a.m., ranged from 7.0 to $23.5^{\circ} \mathrm{C}$, and averaged $15.7^{\circ} \mathrm{C}$. It was assumed that in these conditions the development of $C$. vicina would take from 27.7 to 29.8 days. During the first collection of material, on the second day after the death of the dog, a countless number of eggs and the appearance of the first larval instar of flies were observed, as well as adult forms of $C$. vicina. Eggs and first-instar larvae were collected regularly on subsequent days as well, up to and including the $36^{\text {th }}$ day after the death of the animal. Material from days 11 to 15 after the death contained second-instar larvae in addition to eggs. The next stage, i.e. the third larval instar, was collected from day 23 to the end of the experiment, and on the $36^{\text {th }}$ day pupae were collected as well. The developmental stages of $C$. vicina are presented in Fig. 6.

An attempt was made to determine time of death on the basis of the developmental cycle of Calliphora vicina. Niederegger et al. conducted a similar study using different foods for blowfly larvae (18). The authors observed the developmental cycle of two species of the family Calliphoridae on minced meat: turkey, beef and a mixture of the two, as well as on non-minced turkey meat and turkey, beef and pork liver. They showed that the development of Calliphora vicina was not influenced by the food substrate, whereas $C$. vomitoria had lower body weight on the non-minced meat in comparison to the minced meat, irrespective of the kind of meat. Both species had a slightly reduced total development time on various types of meat, except for the liver. Comparison of the results obtained in our study shows similar relationships, particularly in the case of the pork liver, where

\begin{tabular}{|c|c|c|c|c|c|c|c|c|c|c|}
\hline \multirow{3}{*}{ Dog } & & & & & .• & ... & & \multirow{2}{*}{\multicolumn{3}{|c|}{ * }} \\
\hline & . & . & . & .. & . & .. & $\ldots$ & & & \\
\hline & 0 & O & & 0 & 0 & . & .. & ... & ... & $\infty$ \\
\hline $\begin{array}{c}\text { Day after } \\
\text { death }\end{array}$ & 2 & 4 & 9 & 11 & 15 & 23 & 25 & 32 & 36 & 40 \\
\hline O eggs & & & $.1 \mathrm{la}$ & ae II & $\ldots$ & vae III & & upae & & nago \\
\hline
\end{tabular}

Fig. 6. Developmental stages of $C$. vicina collected on different days after the death of the $\operatorname{dog}$ in field conditions the developmental cycle in some individuals was 3-5 days longer than on the pork shoulder.

Pork shoulder is mainly a source of complete animal protein and contains little fat. Female blowfly scavengers must feed on protein for their eggs to develop normally (3). The experiment showed that a large amount of protein also leads to a fast development rate. On the other hand, pork and turkey liver, in addition to being a good source of protein, iron and vitamins, also contain toxins that may be the cause of slower larval development.

Variation in the growth and development of necrophagous insects depending on the food source was observed by Rabêlo et al. (20), who reared insects on beef, sardines, chicken egg and rumen tissue. They demonstrated differences in the weight of particular developmental stages of the insects, while their duration and the total time required until they attained their adult forms was similar irrespective of the food used.

Kaneshrajah and Turner (9) reported that growth curves for $C$. vicina larvae differ substantially depending on the type of food. Larvae developed 2 days earlier in brain tissue, lungs, kidneys and heart than in liver.

Clark (2) compared the development of another blowfly species, Lucilia sericata, and also found that the rate of development varied depending on the food source. The author determined that the larvae of this species developed faster on heart and lung tissue from pigs than on liver. The larvae were also longer and transformed into pupae earlier.

Kaczorowska and Draber-Mońko (7) found that the time of development of insects on pork and on turkey liver was similar. The authors also analysed the relationship between the development of the insects and temperature, and noted the presence of adult forms of Calliphora vicina after $20-25$ days at $18-20^{\circ} \mathrm{C}$. In our study, however, the insects feeding on pork liver developed significantly more slowly despite the higher temperature and did not complete their developmental cycle until 29 days after the eggs were laid.

Anderson (1), who also studied the relationship between the development rate of blowflies and temperature, reported that larvae appeared after 19 days at a temperature above $23^{\circ} \mathrm{C}$ and after 21 days at a temperature of $20.6^{\circ} \mathrm{C}$. The objective of the study was to observe the decomposition process and identify the developmental cycle of insects colonizing unburied remains. The mean temperature during the present study was about $21.3^{\circ} \mathrm{C}$, but the presence of adult forms of insects was not noted in any of the groups until after 28 days from the start of the experiment and 24 days after the eggs were laid. Pupae also appeared later than in the study cited; 17 days from the start of the experiment and 13 days after the eggs were laid.

These data indicate that besides temperature, the food source also differentiates the development rate of these flies.

The use of entomological methods to estimate time of death may be particularly helpful in cases where decom- 
position is advanced and post-mortem changes make it impossible to use traditional methods. Payne (19) conducted an experiment on unburied piglet carcasses in the summer in South Carolina (USA). The arthropods studied by Payne belonged to 422 species, and dominant among these were flies (mainly Sarcophagidae, Calliphoridae and Muscidae) and beetles (Histeridae and Staphylinidae), accounting for $60 \%$ of the insects collected.

In the temperate climate zone a pioneer in research on the succession of insects was Megnin (15), who at the end of the $19^{\text {th }}$ century took up the subject in his work La faune de cadavres. He described 8 forms of unburied remains (fresh carcass, initiation of decay, butyric fermentation, decomposition of proteins, ammoniacal fermentation, drying out of remains, complete desiccation, skeletonization), and his scale is still used today. The scale was modified by Early and Goff (4), who defined 5 stages of decomposition: fresh carcass, bloating, active decay, post-decay and dry remains. Marchenko (13), who conducted research in the former Soviet Union, partially confirmed Early and Goff's theories. In Central Europe the study of fauna of unburied carcasses was undertaken by Grassberger (5), who presented his results in a table describing 42 species belonging to 20 arthropod families.

The results of our analysis of the fauna colonizing a dog carcass during the spring in the temperate climate zone of Poland confirm the occurrence of the same arthropods and indicator species used to determine time of death in the case of carcasses of other animal species. The time from the appearance of eggs and first-instar larvae to the development of second-instar larvae is 9 days, while third-instar larvae appeared after 21 days and pupae were found 34 days after the start of the experiment. This is somewhat longer than in the results obtained by Kamal (8) and by Kaczorowska and DraberMońko (7), but daily fluctuations in temperature, which dropped significantly at night, should be taken into account, as this may have prolonged the developmental cycle of the blowfly.

Experiments on dog carcasses may in the future contribute to the development of research enabling determination of the time of death of animals, which is a subject of increasing interest in forensic veterinary medicine. Special research facilities called body farms are devoted to the study of decomposition processes and necrophagous fauna colonizing human corpses (16). Unfortunately, there are no such facilities in Poland, mainly for cultural, bioethical and legal reasons, which greatly impedes the development of forensic entomology and research on the succession of arthropods in our region. Therefore research on animals has a chance to contribute to the development of entomological methods used in forensic medicine in Poland and to popularization of this research method among judicial bodies.

Forensic entomology, using knowledge on the biology of necrophagous insects, makes it possible to determine the date and sometimes even the place and causes of death. The length of the developmental cycles of insects depends on ambient conditions, so studies should take as many criteria as possible into account. Succession of arthropods, as well as the species composition and indicator insects of particular stages of decomposition, is very similar in human and animal carcasses, which may facilitate research, e.g. due to ethical considerations. Forensic entomology has a strong chance of replacing traditional methods for determining time of death, particularly in cases when more time has passed since death.

\section{References}

1. Anderson G. S.: Minimum and maximum development rates of some forensically important Calliphoridae (Diptera). J. Forensic Sci. 2000, 45, 824-832.

2. Clark K., Evans L., Wall R.: Growth rates of the blowfly, Lucilia sericata, on different body tissues. Forensic Sci. Int. 2006, 156, 145-149.

3. Draber-Mońko A.: Calliphoridae, Plujki (Insecta: Diptera). Fauna Polska 2004, 23, 1-659.

4. Early M., Goff M. L.: Arthropod succession patterns In expose carrion on the Island of O'ahu, Hawaiian Islands, USA. J. Med. Entomol. 1986, 23, 520-531.

5. Grassberger M., Frank C.: Initial Atudy of Arthropod Succession on Pig Carrion in a Central European Urban Habitat. J. Med. Entomol. 2004, 41, 511-523.

6.Henssge C.: Temperature-based methods II, [in:] Knight B. (ed.): The Estimation of the Time Since Death in the Early Postmortem Period. Arnold, London 2002, p. 43-102.

7. Kaczorowska E., Draber-Mońko A.: Wprowadzenie do entomologii sądowej. Wydawnictwo Uniwersytetu Gdańskiego, Gdańsk 2010, p. 106-121.

8. Kamal A. S.: Comparative study of thirteen species of sarcosaprophagous Calliphoridae and Sarcophagidae (Diptera). 1. Bionomics. Ann. Entomol. Soc. Am. 1958, 51, 261-271.

9. Kaneshrajah G., Turner B.: Calliphora vicina larvae grow at different rates on different body tissues. Int. J. Legal Med. 2004, 118, 242-244.

10. Knight B., Nokes L.: Temperature-based methods I, [in:] Knight B. (ed.): The Estimation of the Time Since Death in the Early Postmortem Period. Arnold, London 2002, p. 3-42.

11. Listos P., Gryzinska M., Kowalczyk M.: Analysis of cases of forensic veterinary opinions produced in a research and teaching unit. J. Forensic Legal Med. 2015, 36, 84-89.

12. Listos P., Gryzinska M., PiorkowskiJ., Teresinski G., Buszewicz G., Chagowski W., Nozdryn-Plotnicki Z., Lopuszynski W.: Post-mortem estimation of time of death of dogs based on measurements of kidney temperature in comparison with rectal temperature. Acta Vet. Beograd 2016, 66, 76-88.

13. Marchenko M. I.: Medicolegal relevance of cadaver entomofauna for the determination of the time of death. Forensic Sci. Int. 2001, 120, 89-109.

14. Matuszewski S., Bajerlein D., Konwerski S., Szpila K.: Entomologia sądowa w Polsce. Wiad. Entomol. 2008, 27, 49-52.

15. Mégnin J. P.: La faune de cadavres. Application de 1'entomologie a la médicine légale. Encyclopedie Scientifique des Aides-Mémoire. Masson, Paris Gauthier-Villars, Paris 1894, p. 1-214.

16. Mikołajczyk B.: Czy Bill Bass zostałby w Polsce skazany? Art. 262 k.k. a rozwój kryminalistyki w kontekście działalności tzw. „farmy śmierci”. III Dni Kryminalistyki Wydziału Prawa i Administracji Uniwersytetu Rzeszowskiego. Mat. konf., Rzeszów 2009, p. 301-313.

17. Munro R., Munro H. M.: Some challenges in forensic veterinary pathology: a review. J. Comp. Pathol. 2013, 149, 57-73.

18. Niederegger S., Wartenberg N., Spiess R., Mall G.: Influence of food substrates on the development of the blowflies Calliphora vicina and Calliphora vomitoria (Diptera, Calliphoridae). Parasitol. Res. 2013, 112, 2847-2853.

19. Payne J. A.: A summer carrion study of the baby pig, Sus scrofa (L.). Ecology $1965,46,592-602$.

20. Rabêlo K. C., Thyssen P. J., Salgado R. L., Araújo M. S., Vasconcelos S. D.: Bionomics of two forensically important blowfly species Chrysomya megacephala and Chrysomya putoria (Diptera: Calliphoridae) reared on four types of diet. Forensic Sci. Int. 2011, 210, 257-262.

21. Saukko P., Knight B.: Knight's Forensic Pathology. Arnold, London 2004, p. 52-97.

Corresponding author: Piotr Listos, DVM, PhD, ul. Głęboka 30, 20-612 Lublin; e-mail: piotr.listos@up.lublin.pl 